\title{
Bilateral nonarteritic anterior ischemic neuropathy following acute angle-closure glaucoma in a patient with iridoschisis: case report
}

\author{
Neuropatia óptica isquêmica anterior não arterítica bilateral após crise de fechamento angular \\ num paciente com iridosquise: relato de caso
}

André Torricelli ${ }^{1}$, Alexandre Soares Castro Reis ${ }^{1}$, Julio Zaki Abucham ${ }^{1}$, Ricardo Suzuki ${ }^{1}$, Roberto Freire Santiago Malta ${ }^{1}$, Mário Luiz R. Monteiro ${ }^{1}$

\begin{abstract}
A 55-year-old woman was referred to our clinic because of a one-week history of visual loss and raised intraocular pressure in the left eye followed 4 days later by visual loss in the right eye. Slit-lamp examination showed bilateral conjunctival hyperemia, slight diffuse corneal edema, shallow anterior chamber and fixed and dilated pupil in both eyes. Splitting of the anterior layers of the iris with fibrillar degeneration extending for approximately one quadrant inferiorly was presented in each eye. Fundus examination showed opitc disc edema with no vascular tortuosity and no cup in both eyes. The condition was treated as bilateral acute angle-closure glaucoma in a patient with irisdoschisis. After medical treatment and improvement of visual acuity, perimetry revealed a significant visual field defect especially in left eye; this case represents a rare concurrence of acute angle-closure glaucoma and bilateral nonarteritic ischemic optic neuropathy. Although most cases of elevated intraocular pressure, including acute angle-closure glaucoma, do not result in optic disc edema and irreversible vision loss, variations in the vascular supply of the nerve optic head along with others ocular systemic risk factors, may predispose certain individuals to nonarteritic ischemic optic neuropathy during periods of elevated intraocular pressure.
\end{abstract}

Keywords: Iris diseases/diagnosis; Glaucoma, angle-closure; Optic neuropathy, ischemic; Case reports

\begin{abstract}
RESUMO
Paciente de 55 anos, sexo feminino, encaminhada para nosso serviço com história de perda de visão e aumento da pressão intraocular no olho esquerdo há uma semana seguida quatro dias após de perda visual no olho direito. À biomicroscopia hiperemia conjuntival bilateral, edema difuso da córnea, câmara anterior rasa e pupilas fixas e dilatadas em ambos os olhos. Separação do folheto anterior da íris no quadrante inferior estava presente em ambos os olhos. O exame do fundo do olho mostrava edema de disco sem tortuosidade vascular e sem escavação em ambos os olhos. 0 quadro clínico foi tratado como crise de fechamento angular bilateral num paciente com iridosquise. Após tratamento clínico e iridotomia bilateral com melhora da acuidade visual, a perimetria computadorizada revelou grave perda de campo visual, especialmente no olho esquerdo; este caso representa a rara ocorrência simultânea de crise de fechamento angular e neuropatia óptica isquêmica anterior não-arterítica bilateral. Embora a maioria dos casos com pressão intraocular elevada, incluindo crise de fechamento angular, não resulta em edema de disco e perda visual irreverssivel, variações no suprimento vascular da cabeça do nervo óptico associados com outros fatores de risco sistêmicos, podem predispor certos indivíduos à neuropatia óptica isquêmica anterior durante períodos de elevação da pressão intraocular.
\end{abstract}

Descritores: Doenças da iris/diagnóstico; Glaucoma de angulo fechado; Neuropatia óptica isquêmica; Relatos de casos

\section{INTRODUCTION}

ridoschisis is a rare condition characterized by bilateral separation of the iris stroma, most commonly in the inferior quadrants of the eye. Glaucoma, mainly of the angle-closure type, occurs in approximately $50 \%$ of cases $^{(1)}$. The condition usually presents as a defect in the iris of older patients and by itself is rarely associated with ocular dysfunction although visual loss from corneal decompensation ${ }^{(2)}$ or glaucoma may occur. In this paper, we report a patient that developed visual loss as a result of bilateral ischemic optic neuropathy following acute angle-closure glaucoma.

\section{CASE REPORT}

A 55-year-old woman was referred to our clinic because of a one-week history of visual loss and raised intraocular pressure in the left eye (OS) followed 4 days later by visual loss in the right eye (OD). Glaucoma medication had been prescribed elsewhere without

\footnotetext{
Work carried out at the Department of Ophthalmology - University of São Paulo - USP. Physicians, Division of Ophthalmology, Faculdade de Medicina, Universidade de São Paulo - USP São Paulo (SP), Brazil.

Correspondence address: André Torricelli. Rua Vieira de Morais, 74 - Apto. 111A - São Paulo (SP) Zip Code 04617-000 - E-mail: andre_torri39@yahoo.com.br

Recebido para publicação em 27.09.2009

Última versão recebida em 07.02.2010

Aprovação em 08.02.2010
}

clinical improvement. Past medical history was completely unremarkable. On examination, visual acuity was hand movements in OD and light perception in OS. Slit-lamp examination showed bilateral conjunctival hyperemia, slight diffuse corneal edema, shallow anterior chamber and fixed and dilated pupil in both eyes. Splitting of the anterior layers of the iris with fibrillar degeneration extending for approximately one quadrant inferiorly was present in each eye. The clinical appearance was consistent with iridoschisis. Intraocular pressure was $42 \mathrm{mmHg}$ in $\mathrm{OD}$ and $44 \mathrm{mmHg}$ in OS. Gonioscopy revealed that the patient had narrow angles (Shaffer grade 0 ) for $360^{\circ}$ in OU. Ultrasound biometry revealed axial lengths on A-scan of $20.42 \mathrm{~mm}$ in OD and $20.09 \mathrm{~mm}$ in OS. Fundus examination showed opitc disc edema with no vascular tortuosity and no cup in OU. Medical treatment with timolol, brimonidine, pilocarpine, prednisolone eye drops, manitol and acetazolamide, followed by YAG laser iridectomy achieved satisfactory IOP control. Two months later the best corrected visual acuity was 20/20 in OD and 20/200 in OS. Intraocular pressure was $11 \mathrm{mmHg}$ OU with no medication and patent iridectomies. Optic disc edema progressively resolved and was followed by optic disc pallor in OU (Figure 1). Visual perimetry revealed a significant visual field defect especially in OS (Figure 2).

\section{DISCUSSION}

Iridoschisis is a rare disease with approximately 100 cases reported in the literature to date ${ }^{(3)}$. Most patients are over 65 years 

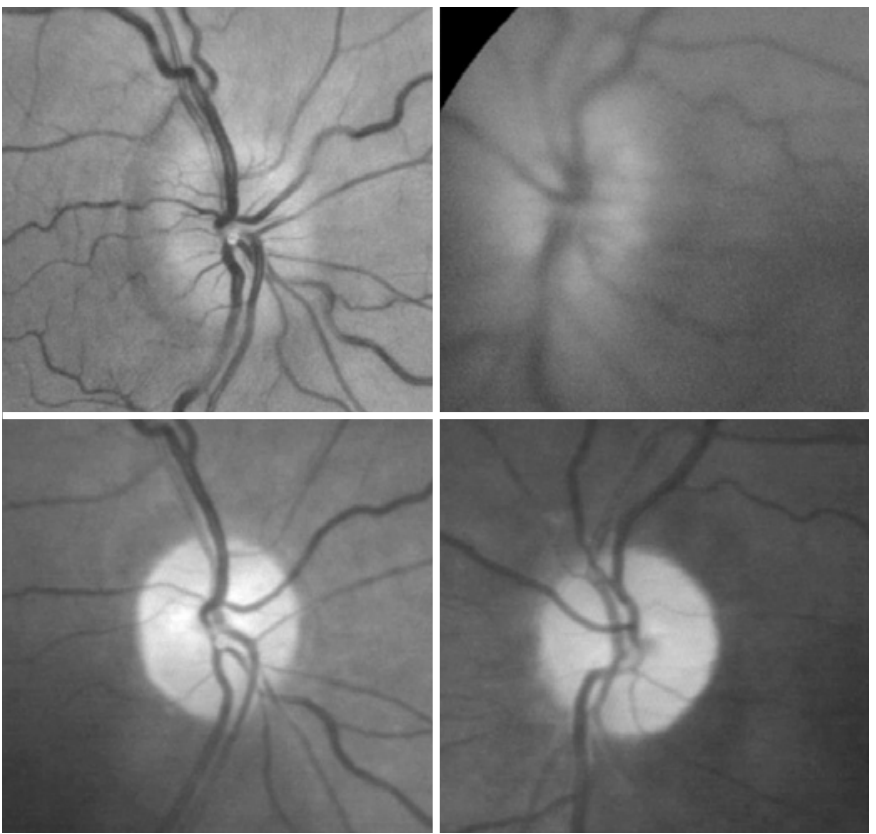

Figure 1. Fundus photograph.
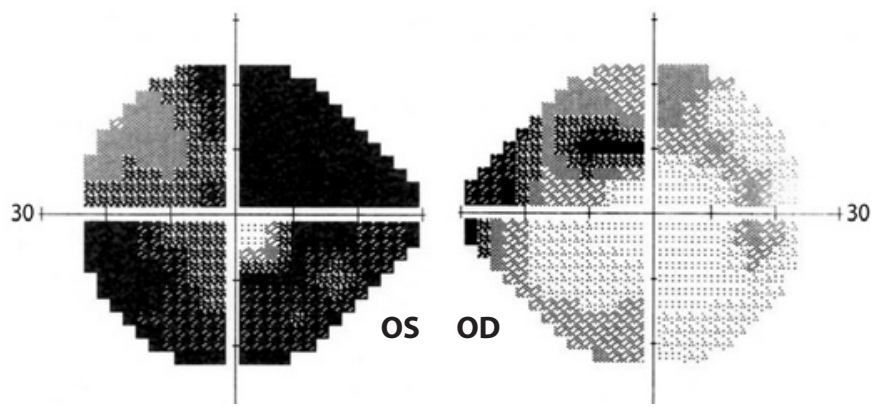

Figure 2. Visual field evidencing the visual loss.

old and the condition is usually bilateral. The etiopathogenesis is not clearly understood but has most commonly been considered as an age-related atrophy ${ }^{(4)}$. Visual loss is uncommon, usually caused by glaucoma, maily angle-closure from pupillary block, and corneal decompensation secondary to iridocorneal touch ${ }^{(2,5)}$. The prognosis of the visual loss in acute angle-closure glaucoma (AACG) is related with the duration and the severity of acute attack; a long duration of acute attack and very high IOP may cause permament damage to the optic disk.

Nonarteritic anterior ischemic optic neuropathy (NAION) is the most common cause of acute optic neuropathy after age 50, but may also occur in younger patients. NAION is presumably secondary to small vessel disease of the short posterior ciliary arteries, with resultant hypoperfusion and infarction of the anterior optic nerve. The diagnosis is based on clinical findings including painless visual loss associated with a relative afferent pupillary defect and disc edema. In almost all cases, there is an underlying crowded optic disc with a small cup-to-disc ratio. The visual prognosis is usually poor, although up to $43 \%$ of patients may improve over time. The fellow eye is involved in up to $15 \%$ of patients within 5 years, but the risk of recurrence in the same eye is less than $5 \%$. There is no treatment for acute NAION but it is essential to evaluate these patients for underlying treatable atheromatous vascular risk factors and to prevent precipitating factors such as blood loss, sleep apnea syndrome or nocturnal hypotension ${ }^{(6-8)}$.
The association of NAION with acute glaucoma has been described in only a few reports, Slavin et al. ${ }^{(9)}$ in 2001 reported a case of NAION developing in both eyes of a patient that developed sequential acute angle-closure glaucoma; Irak I et al. ${ }^{(10)}$ in 2003 described a 41-year-old woman with NAION and glaucomatocyclitic crisis (Posner-Schlossman syndrome) and Nahum Y et al. ${ }^{(11)}$ in 2008 described a 59-year-old hyperopic woman with NAION following by a acute angle-closure glaucoma. In these reports, NAION was attributed to an acute IOP rise with resultant perfusion decrease in optic nerve supplying vessels.

Fundoscopic examination in previously reported cases and the patient presented in this paper demonstrate diffuse optic disc edema with or without hemorrhages on the disc margin and the presence of a small cup-to-disc ratio. Automated perimetry in previously reported cases revealed: a superior altitudinal visual field defect, dense superior and inferior arcuate defects and an inferior altitudinal defect ${ }^{(9-11)}$. Most of these clinical characteristics are similar to those found in cases with typical NAION, not related to glaucoma although in the latter the disc edema tends to be segmental and the altitudinal field defect generally occurs inferiorly. The presence of optic disc with small or absent physiologic cup is a frequent finding in both in typical NAION and in cases secondary to acute glauco$m a^{(6-7)}$. Therefore, although we can find some differences and similarities in clinical findings of patients with NAION after acute rise of IOP and patients with typical idiopathic NAION, the number of cases of NAION after acute glaucoma is so small that one a clear distinction between the two modalities of ischemic optic neuropathies cannot be established.

NAION triggered by acute glaucoma should also be differentiated from the usually mild, optic disc edema that has been observed acute elevation of the intraocular pressure ${ }^{(1)}$. In fact, congested and edematous optic discs were observed in the first week after experimentally induced acute glaucoma in the owl monkey. A marked reduction in the blood flow was observed in the optic nerve indicating that the general mechanism of optic disc damage in acute glaucoma is ischemic ${ }^{(12)}$. Therefore although clear-cut cases of acute glaucoma induced NAION as the one we describe here are extremely uncommon, the presence of optic mild disc edema before cupping develops indicates that some form of optic disc ischemia are probably relatively common after acute glaucoma. The differentiation from true cases of NAION, however, is that frank optic disc edema and typical altitudinal visual field defect does not usually develop after acute glaucoma.

To our knowledge our case is the first patient reported with bilateral and simultaneous NAION associated with AACG secondary to iridoschisis. Based on the previous above mentioned reports, we believe that raised intraocular pressure was probably the main precipitating factor for the development of NAION. Furthermore, our patient had crowded disc, with bilateral small cup-to-disk ratio which may have contributed for the development of NAION. Although most cases of elevated IOP, including acute angle-closure glaucoma, do not result in optic disc edema and irreversible vision loss, variations in the vascular supply of the nerve optic head along with others ocular systemic risk factors, may predispose certain individuals to NAION during period of elevated IOP(10). Our patient therefore is important because it serves to emphasize that elevated intraocular pressure may be a precipitating factor for the development of NAION. Intraocular pressure reduction should be achieved as soon as possible to avoid such dreadful complication.

\section{REFERENCES}

1. Shieds MB, editor. Textbook of glaucoma. $3^{\text {rd }}$ ed. Baltimore: Willians \& Wilkins; 1992.

2. Srinivasan S, Batterbury M, Hiscott P. Bullous keratopathy and corneal decompensation secondary to iridoschisis: a clinicopathological report. Cornea. 2005;24(7):867-9.

3. Danias J, Aslanides IM, Eichenbaum JW, Silverman RH, Reinstein DZ, Coleman DJ. Iridoschisis: high frequency ultrasound imaging. Evidence for a genetic defect? Br J Ophthalmol. 1996; 80(12):1063-7.

4. Agrawal S, Agrawal J, Agrawal TP. Iridoschisis associated with lens subluxation. J Cataract Refract Surg. 2001;27(12): 2044-6. 
5. Salmon JF, Murray AD. The association of iridoschisis and primary angle-closure glaucoma. Eye (Lond). 1992; 6(Pt 3):267-72.

6. Luneau K, Newman NJ, Biousse V. Ischemic optic neuropathies. Neurologist. 2008;14(6): 341-54. Review.

7. Monteiro ML. Anterior ischemic optic neuropathy: a comparison of the optic disc area of patients with the arteritic and non-arteritic forms of the disease and that of normal controls. Arq Bras Oftalmol. 2006;69(6):805-10.

8. Moura FC, Cunha LP, Monteiro ML. Bilateral visual loss after liposuction: case report and review of the literature. Clinics (Sao Paulo). 2006;61(5):489-91.
9. Slavin ML, Margulis M. Anterior ischemic optic neuropathy following acute angle-closure glaucoma. Arch Ophthalmol. 2001;119(8):1215. Comment in: Arch Ophthalmol. 2002; 120(3):406.

10. Irak I, Katz BJ, Zabriskie NA, Zimmerman PL. Posner-Schlossman syndrome and nonarteritic anterior ischemic optic neuropathy. J Neuroophthalmol. 2003;23(4):264-7.

11. Nahum $Y$, Newman $H$, Kurtz S, Rachmiel R. Nonarteritic anterior ischemic optic neuropathy in a patient with primary acute angle-closure glaucoma. Can J Ophthalmol. 2008;43(6):723-4.

12. Zimmerman LE, De Venecia G, Hamasaki DI. Pathology of the optic nerve in experimental acute glaucoma. Invest Ophthalmol. 1967;6(2):109-25. 